\title{
A multiple knowledge approach for adaptation to environmental change: lessons learned from coastal Louisiana's tribal communities
}

\author{
Julie Koppel Maldonado ${ }^{1}$ \\ American University, Washington DC, USA
}

\begin{abstract}
Environmental changes, such as sea level rise, are forcibly displacing communities around the world. Forced displacement, inadequate governance mechanisms to address relocation and economic-based adaptation and restoration efforts are leading to devastating social, cultural, health, and economic consequences for the people and communities affected. This article focuses on three tribal communities in coastal Louisiana that are experiencing rapid environmental change and risk of displacement due to historical discriminatory processes, oil and dam-related development projects, oil disasters, increased exposure to hurricanes, and relative sea level rise. Focusing on the political ecology of the communities' experiences of environmental change, including the impacts of displacement and decisions to stay in-place vs. relocate, this paper addresses broader issues of adaptive governance structures and policy implications. Building on Bronen's (2011) rights-based approach to adaptation and Shearer's (2012) approach to a political ecology of adaptation, I argue that governance structures should be put in place that support communities' in-situ adaptation efforts or, if the community decides its current location is no longer inhabitable, to assist community-led relocation efforts. Multiple forms of knowledge should be incorporated into and should inform the structures supporting the adaptation process. I highlight the social, political, environmental and economic context within which environmental changes are occurring in coastal Louisiana through discussion on the loss of the commons, the creation of an energy sacrifice zone, costbenefit based restoration efforts and forced displacement and relocation.
\end{abstract}

Key words: Environmental change, displacement, relocation, adaptation

\section{Résumé}

Les changements environnementaux , tels que l'élévation du niveau de la mer, déplacent des communautés du monde entier. Le déplacement forcé, les mécanismes de gouvernance appropriées pour faire face a la réinstallation, et l'adaptation à base économique et les efforts de restauration sont en tête des conséquences sociales, culturelles, sanitaires et économiques dévastatrices pour les personnes et les communautés touchées. Cet article se concentre sur trois communautés tribales en Louisiane côtière. Ils connaissent le changement rapide de l'environnement et le risque de déplacement en raison de processus historiques discriminatoires, les projets de pétrole et de développement des barrages, les catastrophes pétrolières, l'exposition accrue aux ouragans, et l'élévation relative du niveau de la mer. Ce document aborde les questions plus larges de structures de gouvernance adaptative et implications politiques, en mettre l'accent sur l'écologie politique de l'expérience des communautés des changements environnementaux, y compris les effets de déplacement et les décisions de rester en place contre délocaliser. Je construis une approche d'une écologie politique de l'adaptation fondée sur les droits démarche d'adaptation, suivant Bronen (2011) et Shearer (2012). Je soutiens que les structures de gouvernance doivent être mis en place afin que les les efforts d'adaptation des communautés in-situ sont pris en charge ou, si la communauté décide de son emplacement actuel n'est plus habitable, pour aider les efforts de réinstallation menés par la communauté. Multiples formes de la connaissance devraient être intégrées dans les structures de soutien du processus d'adaptation, et devraient les informer. Je souligne le contexte social, politique, environnemental et économique dans lequel les changements environnementaux se produisent en Louisiane côtière. Cela

\footnotetext{
${ }^{1}$ Julie Koppel Maldonado, PhD Candidate, Department of Anthropology, American University, Washington DC, USA. E-mail: jk6582a "at" student.american.edu. A very special thank you to the residents of Isle de Jean Charles, Pointeau-Chien and Grand Caillou/Dulac for welcoming me into their homes and for all of their love, time, support, good humor and food. Thank you also to Kristina Peterson for her mentoring, passion, compassion and inspiration. And thank you to Josiah Heyman and the reviewers for their helpful suggestions in revising this paper.
} 
comprend la perte des biens communs, la création d'une zone de sacrifice de l'énergie, les efforts de restauration basées sur l'analyse coûts-avantages, et des déplacements forcés et des délocalisations.

Mots clés: changements environnementaux, de déplacement, de réinstallation, l'adaptation

\section{Resumen}

Cambios ambientales, como el aumento del nivel del mar, están desplazando de manera forzada comunidades en todo el mundo. Desplazamiento forzado, mecanismos de gobernanza inadecuados para hacer frente a la reubicación y adaptación basada en los esfuerzos de restauración económica están dando lugar a consecuencias sociales, culturales, en la salud y económicas devastadoras para las personas y comunidades afectadas. Este artículo se centra en tres comunidades tribales en la costa de Louisiana que están experimentando un rápido cambio ambiental y riesgo de desplazamiento debido a procesos de discriminación históricos, proyectos de desarrollo relacionados con petróleo y represas, los desastres del petróleo, la creciente exposición a huracanes, y el aumento relativo del nivel del mar. Centrándose en la ecología política de las experiencias del cambio ambiental de las comunidades, incluyendo los impactos del desplazamiento y las decisiones de permanecer en el lugar frente a la reubicación, este artículo aborda cuestiones más amplias de estructuras de gobernanza adaptativas e implicaciones políticas. Basándose en el enfoque de adaptación basado-en-derechos de Bronen (2011) y en el enfoque de la política ecológica de la adaptación de Shearer (2012), argumento que las estructuras de gobernanza deben soportar los esfuerzos de adaptación in-situ de las comunidades, o si la comunidad decide que su ubicación actual ya no es habitable, asistir los esfuerzos de reubicación dirigidos por la comunidad. Múltiples formas de conocimiento deben ser incorporados en y deben informar las estructuras que soportan el proceso de adaptación. Destaco el contexto social, político, ambiental y económico dentro del cual los cambios ambientales están ocurriendo en la costa de Luisiana a través del debate sobre la pérdida de los comunes, la creación de una zona de sacrificio de energía, los esfuerzos de restauración basados en costo-beneficio y el desplazamiento forzado y la reubicación.

Palabras clave: Cambio ambiental, desplazamiento, reubicación, adaptación

\section{Introduction}

If we lose the Island we lose what brings us back to it. And that's the idea that that was our place. It was our place. Everybody else can say the government considered it uninhabitable, and we took it and inhabited and we made it our place, and now it's gone. It's going. And if it goes we'll no longer have our special place. That's the one thing that keeps us together as a community, as a reservation, is we had our place. We don't have our place anymore. We have no place.

Tribal Member, Isle de Jean Charles Band of Biloxi-Chitimacha-Choctaw Indians, Louisiana

The Isle de Jean Charles and Grand Caillou/Dulac Bands of Biloxi-Chitimacha-Choctaw Indians and Pointe-au-Chien Indian Tribe are three small, state-recognized Native American communities in coastal Louisiana. Historically they have been fishers, trappers, farmers and hunters and include descendants of Biloxi, Chitimacha, Choctaw, Acolapissa and Atakapa Indians. Forcibly displaced from their homelands by French settlers in the 1700s, the bayous served as a refuge for their ancestors to escape to the dense forested swamps deemed uninhabitable by white settlers. Today, external forces destroying the tribes' surrounding environment threaten their culture, water-based settlements and livelihoods. The tribes are experiencing rapid environmental change and risk displacement due to historical discriminatory processes, oil and dam-related development projects, oil disasters, increased exposure to hurricanes and relative sea level rise.

Human-induced environmental changes, such as the impacts of climate change and unsustainable development practices (e.g., oil extraction and exploration), are displacing millions of people around the 
world (IPCC 2007; UNDP 2007/2008). In particular, entire indigenous communities living in coastal and low-lying areas that already face a multitude of stressors are being forced to relocate due to accelerated sea level rise, erosion, extreme weather events and/or permafrost thaw (Bronen 2011; Louisiana Workshop 2012; Maldonado et al. 2013; McLean et al. 2009; NCADAC 2013).

Such issues are often framed as environmental problems. However, environmental change and its impacts are "symptoms of deeper pathologies of power" (Farmer 2003:7), made visible through forms of structural power reflected in the prevailing economic, political and social systems (Austin 2004; Wolf 1999). Environmental degradation is a form of tacit persecution. Modern economic and political processes positioned humans and the environment in conflict, masked such destruction, and established a framework that led to the overconsumption of natural resources and the disconnect between consumption, production and environmental degradation (Foster 1999; Kütting 2004; Marx 1994/1888).

Over the past several decades, political ecology frameworks have unpacked the ways dominant Western views of nature-culture relations and capitalist economic perspectives create social inequality (Escobar 1996; Oliver-Smith 2009; Peet and Watts 1996; Stonich and DeWalt 2006). For example, socalled "natural" disasters highlight local pre-existing socio-economic inequalities and reproduce those inequalities as the disaster unfolds (Button and Oliver-Smith 2008; Oliver-Smith 1999; Reed 2008). Disaster researchers have encouraged a shift from viewing vulnerability to disasters as stemming from abnormal events or geophysical situation of a place to being explained through the everyday social order and systems of domination and inequality (Hewitt 1983; Hilhorst and Bankoff 2004; Oliver-Smith 2004; Quarantelli 1998; Wisner 2004).

The drastic environmental changes the three Louisiana tribes face highlight the greater contradictions in our social, political and economic system and the need to make decisions under increasingly uncertain and complex conditions (Austin 2004; Watts 1983). The tribes' experiences show the interaction between the environmental, social and political processes and governing power dynamics. Focusing on the political ecology of the communities' experiences of environmental change, including the impacts of displacement and decisions to stay in-place vs. relocate, this paper addresses broader issues of adaptive governance structures and policy implications. Building on Bronen's (2011) rights-based approach to adaptation and Shearer's (2012) approach to a political ecology of adaptation, I argue that governance structures should be put in place that support communities' in-situ adaptation efforts or, if the community decides its current location is no longer inhabitable, assist community-led relocation efforts. Multiple forms of knowledge should be incorporated into and inform the structures supporting the adaptation process. I highlight the social, political, environmental and economic context within which environmental changes have occurred in coastal Louisiana through discussion on the loss of the commons, the creation of an energy sacrifice zone, cost-benefit based restoration efforts and forced displacement and relocation.

\section{Methodology}

I initially visited coastal Louisiana in September 2009 and returned in June and July 2010. I then spent nine months conducting dissertation fieldwork between October 2011 and September 2012 and have continued to spend time with the communities every few months in 2013. My goal was to understand the lived experience of displacement - physical, economic, social and cultural - for people in-place and those that have relocated. To conduct my research, I employed a variety of methods: participant observation (e.g., shrimping and attending community meetings); intentional conversations, in which I wove specific topics into longer one-on-one conversations, with the goal of providing more culturally appropriate space for conversation as opposed to a formal interview with a confined set of questions; cross-community conversations, which brought people together through online communication to learn from each other's experiences of facing severe environmental changes; digital storytelling, which are short narratives created in video format that bring together participants' words, voices and pictures; and story circles. Between the three communities, fifty-six people participated in intentional conversations and/or story circles and five people created complete digital stories. These methods helped me better understand the long history of displacement and environmental degradation that the three tribes experienced and drew out people's reflections about the environmental changes in ways that they might not have otherwise revealed. For example, by having community members share stories together around a table or looking through family photos, the multiple realities and timeframes within which they found themselves emerged in different 
ways. The participatory-based methodological approach allowed for a greater understanding of the social, political, economic and ecological processes that have taken place to form, shape and re-shape the landscape the tribes have called home for centuries.

\section{The ecology of coastal Louisiana}

Home to over two million people (Coastal Protection and Restoration Authority of Louisiana/CPRA 2012) and containing the seventh largest delta in the world (Couvillion et al. 2011), coastal Louisiana is an intricate web of diverse habitats and landforms, such as natural levees, chenier ridges, barrier islands, forested wetlands and fresh, brackish and saltwater marshes connected together in an ecosystem of deltaic plains formed over thousands of years from deposits of sediment from the Mississippi River (Coastal Louisiana Ecosystem Assessment and Restoration/CLEAR 2006; Turner 1997). Located between the Mississippi River on the east and the Atchafalaya River on the west, Louisiana's coastal wetlands are separated by natural deposits of sediment, soil and clay (Austin 2006). The River deposits between several hundred thousand and several million tons of sediment into the Gulf of Mexico every day (Barry 1997: 39).

Coastal Louisiana contains approximately $41 \%$ of the nation's coastal wetlands (Turner 1997), but is experiencing $90 \%$ of the total coastal wetland loss in the continental USA, with 1,880 square miles $(4,869$ $\mathrm{km}^{2}$ ) of land being lost in the last 80 years (Couvillion et al. 2011; CPRA 2012). This amounts to a decrease of about $25 \%$ in land area since 1932, with 25-35 square miles $\left(65-91 \mathrm{~km}^{2}\right)$ of land disappearing every year off coastal Louisiana (Couvillion et al. 2011; NOAA 2013). The organic sediments deposited along the coast go through a natural process of compacting, consolidation and oxidation, resulting in subsidence (Turner 1997). Climate change-induced sea level rise compounds the effects of subsidence (Burkett and Davidson 2012); with an over 8-inch rise in the last 50 years, southeast coastal Louisiana has experienced one of the highest rates of relative sea level rise in the world at slightly faster than twice the global rate (Karl et al. 2009; NOAA 2012; NCADAC 2013). Relative sea level rise - sediment subsidence combined with sea level rise - has far exceeded sediment accretion throughout the Gulf Coast, with the greatest land loss impact occurring in the Deltaic Plain (CLEAR 2006). Dredging canals for oil and gas pipelines and navigation has caused drastic erosion and land loss, as will be discussed in more detail in following sections. With increased impacts from hurricanes and extreme storms, rates of coastal land loss have accelerated in recent years (Couvillion et al. 2011). As saltwater intrudes into the sediment-rich, freshwater areas, the increased salinity destroys the forested wetlands and freshwater marshes (CLEAR 2006).

Furthermore, the largest hypoxic "dead zone" in U.S. coastal waters is in the northern Gulf of Mexico due to increased nutrient concentrations in the Mississippi River (CLEAR 2006; Rabalais et al. 1999). This "dead zone" is largely caused by the impacts of large-scale agricultural development that produce runoff highly contaminated with nitrogen and synthetic chemicals from herbicides and pesticides, as well as runoff containing paper, plastic and motor oil (Morris 2012:5; also CPRA 2012). For an ecosystem that sustains a variety of fish species and shellfish that support the largest commercial fishery in the lower 48 states (CLEAR 2006), such processes can have severe impacts on living resources (Rabalais et al. 1999).

While coastal Louisiana's wetlands undergo a continuous state of change, most of the current environmental change and land loss is due to human-induced causes. A political ecology approach is useful to understand the context of these causes because "humans clearly live not only in an environment constituted by natural processes but also in one of their own making, constituted by human practice and subject to ongoing change and historical transformation" (Watts 1983:40). In coastal Louisiana, the natureculture relationship and the causes of land loss are readily seen through the idea of controlling the ecosystem.

\section{Controlling the ecosystem}

In the Mississippi Valley, the French and American settlers had to show they could "master their environment" (Morris 2012:1). Such ideals date back to the Enlightenment period when "...nature became externalized and objectified, both as an object of knowledge and an object of exploitation" (Haila 1999:49). For example, Descartes' notion of envisioning nature as "other" and Locke's idea of self-realization and 
human freedom linked to control led to exploiting nature to enhance our own lives (Barry 1999; Haila 1999; Oliver-Smith 2004). Thus, controlling the Mississippi River was perfectly suited to the $19^{\text {th }}$ century ideals in which man honed the belief in his rule over the natural world (Barry 1997).

Following the Great Mississippi Flood of 1927, flood protection levees were built and dam and reservoir construction on major tributaries took place along the River. While this river management system put in place by the U.S. Army Corps of Engineers (USACE) and local Levee Districts provided both flood control and economic benefits, such forms of management, control and re-direction of the River have deprived the coastal system of much needed sediment and fresh water (Austin 2006; Barry 1997; Button and Peterson 2009; CPRA 2012; Freudenberg et al. 2009; Laska et al. 2005; Streever 2001; Turner 1997). Instead of collecting along the coast, the sediment brought by the River now goes out into the Gulf of Mexico and drops to the bottom of the sea floor (Morris 2012).

Land loss in coastal Louisiana is often framed as being due to riverine sediment reductions, changing waterways and manipulation of the Mississippi River. When I started my fieldwork, I assumed that people's perspectives about the causes of local environmental changes would be more balanced between the oil industry and manipulation of waterways, e.g., building of dams, levees and other flood protection measures. However, almost everyone I spoke with talked predominantly of the biggest cause of local environmental changes (e.g., land loss, erosion and saltwater intrusion) being the oil industry dredging canals for pipelines (Figure 1,2). As one resident said to me, and this was a common sentiment, "Oil companies got down there and started building canals everywhere, that's when the land started going away."

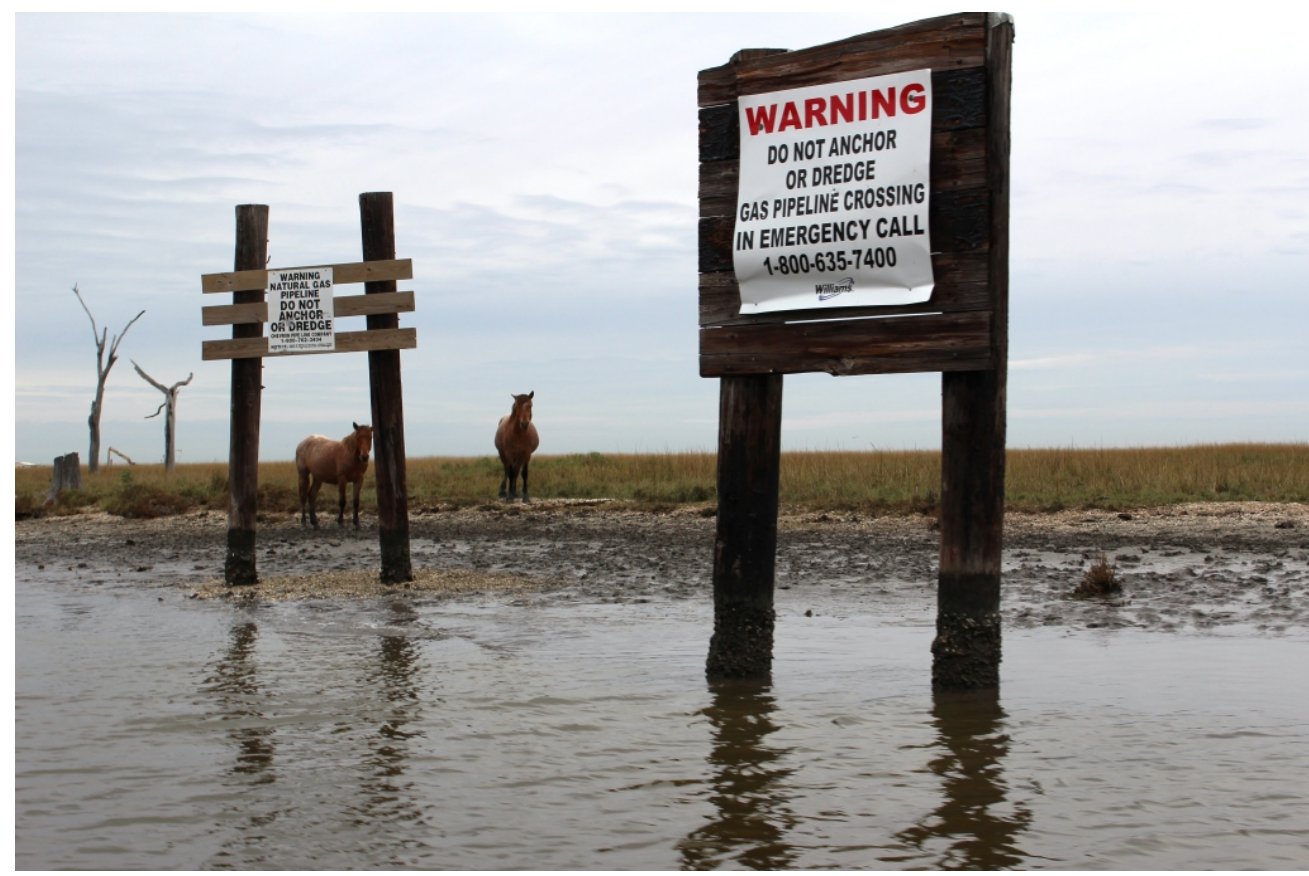

Figure 1: Example of signs marking pipelines. Source: Maldonado, 2012.

The State of Louisiana has historically maintained that land loss is due to sediment deprivation and that restoration needs to be based on sediment management (Turner 1997). Other human-induced factors causing land loss are treated as add-ons in changing the waterways (e.g., CPRA 2012:18; NCADAC 2013:58, 593). However, the tremendous amount of land loss since the 1930s appears to be due to the impacts of changes in wetland hydrology from dredging channels and forming spoil banks (Turner 1997).

Being the country's top crude oil producer and the second largest natural gas producer when including the Outer Continental Shelf (US EIA 2012), by the mid-20 ${ }^{\text {th }}$ century the intense alteration of Louisiana's coastal wetlands rose to full force, concurrent with the extensive onshore and offshore oil and 
gas development and extraction activities, emphasizing private ownership over common resources.

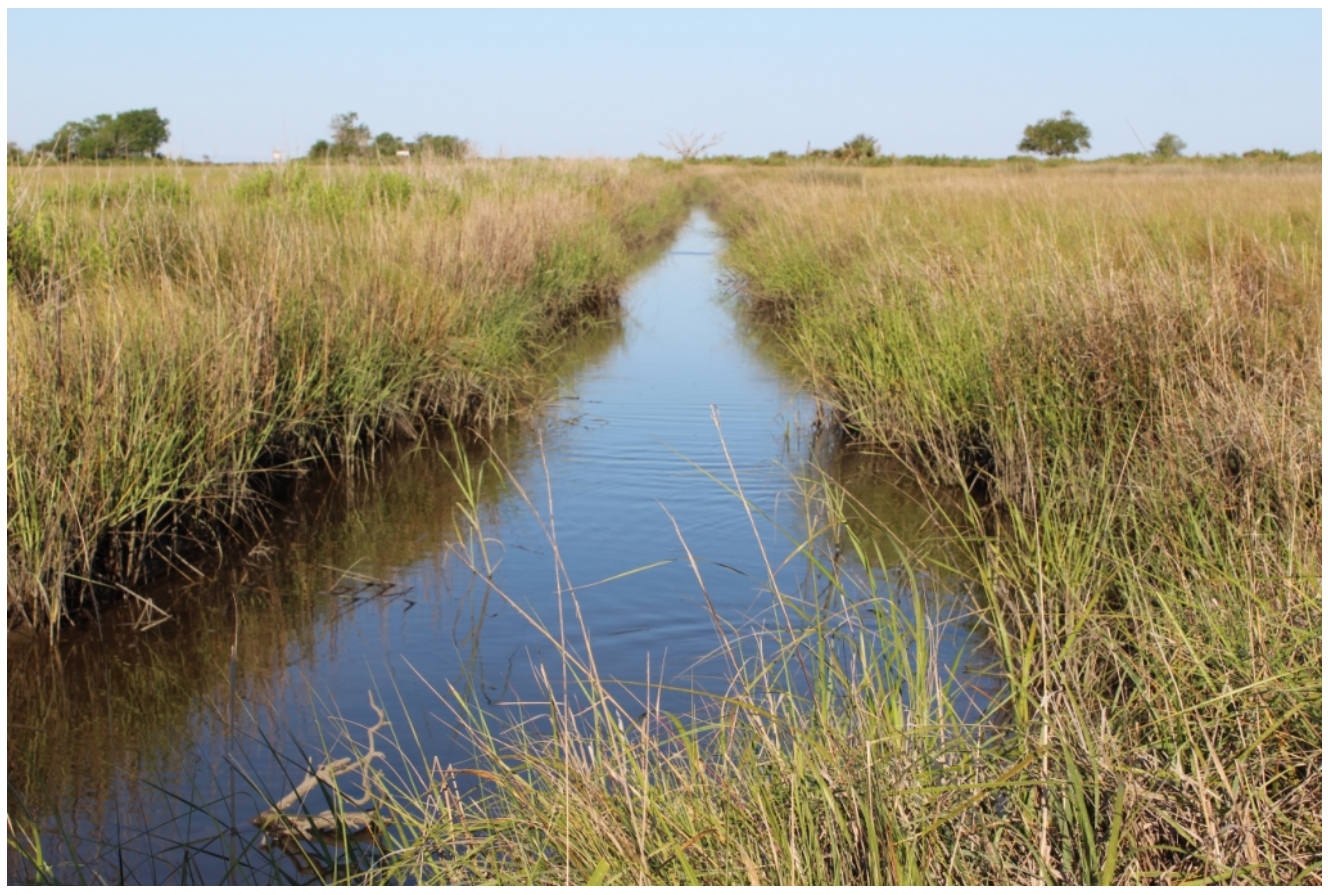

Figure 2: Example of narrow canal from dredging. Source: Maldonado (2012).

\section{A conflicting relationship: private ownership of the commons}

The notion of land ownership was a concept denoted in the Inter Cetera papal bull of 1493, which granted to Spain "...the right to conquer the lands which Columbus had already found, as well as any lands which Spain might 'discover' in the future" (Newcomb 1992). This concept has since fueled the tension between humans and the environment, colonialists and Natives and the idea of private land holdings vs. the commons (Rising Voices Workshop 2013). During the $18^{\text {th }}-19^{\text {th }}$ centuries, the enclosure movement's push for private property further commoditized the natural environment, as well as the anthropocentric thinking that put humans at the center of the world and separated nature from culture (Barry 1999).

Starting in the 1930s, the oil and gas companies, with the backing of the State, cut through Louisiana's coastal marshes and left the once fertile lands barren from saltwater intrusion (Austin 2006). The thousands of miles of dredging for pipelines along Louisiana's coast caused significant land loss and intense coastal erosion and saltwater intrusion (Button and Peterson 2009; Freudenberg et al. 2009; Laska et al. 2005; Turner 1997). These processes, in addition to the flood control measures and the development of the Mississippi River Gulf Outlet, have resulted in severe loss of wetlands and reduced natural protection against hurricanes and storms. The dredged canals get wider and wider as the current and hurricanes pull more marshland away (Figure 3). By the late 1960s, locals started to see the trees and vegetation dying from the intruding saltwater. Before, the bayou communities rarely flooded, but now water can come in with a normal high tide.

The oil and gas industry is embedded in Louisiana's coastal landscape in both subtle and obvious ways. The obvious are the oil rigs dotting the horizon, the straight canals cut through the marsh and the signs in the water, "warning: gas pipeline" (Figure 1). The more subtle ways are through private ownership of the commons and land grabbing. 


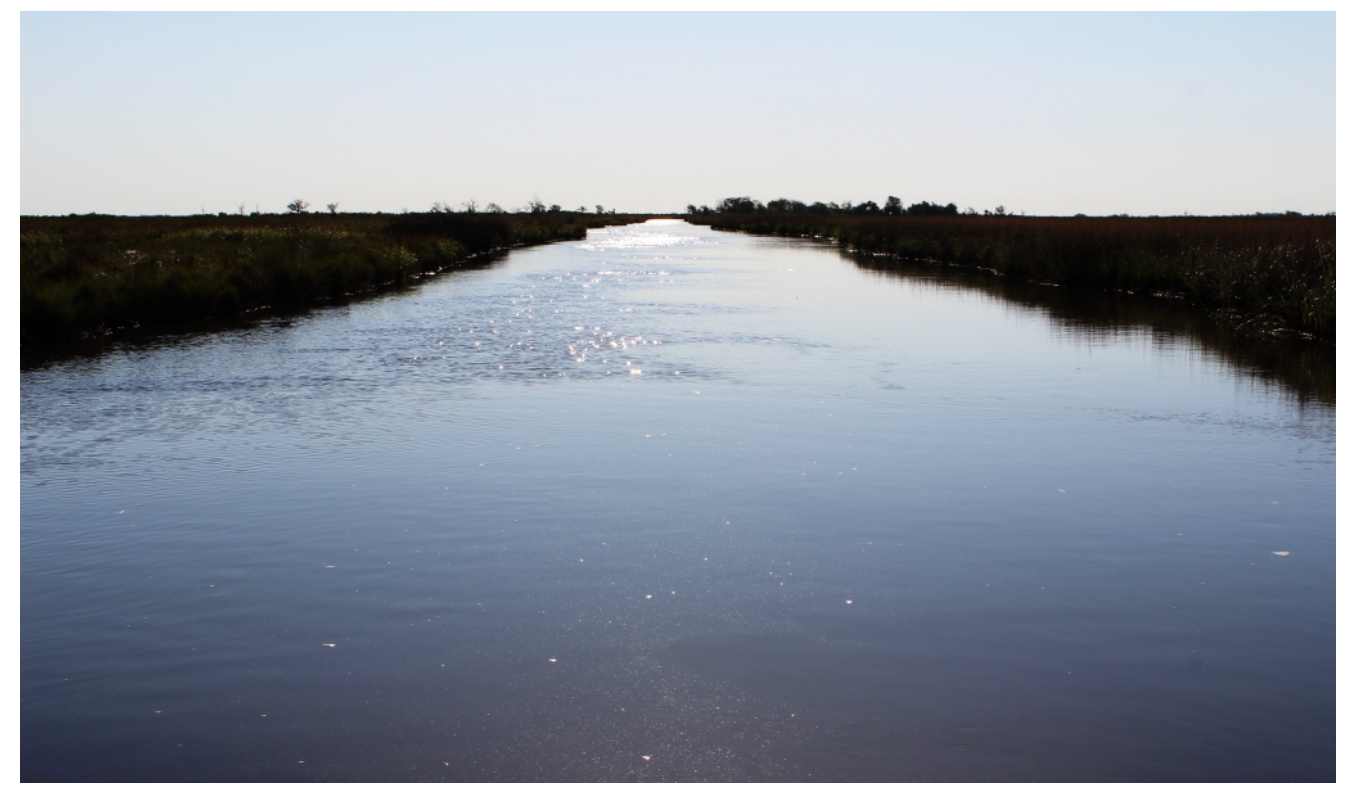

Figure 3: Example of widening canal post-dredging. Source: Maldonado, 2012.

In explaining the "tragedy of the commons," whereby individuals gain by consuming the natural resource at their disposal and will continue to use the resource until it is gone, Hardin argued "freedom in a commons brings ruin to all" (1968:29). The idea of the tragedy of the commons set forth that "...the government should regulate the distribution and use of public goods and control behavior through market and regulatory mechanisms" (Mayo 2010). However, a major flaw with private ownership of the commons is that for resources to not be exploited, "...users must be interested in the sustainability of the particular resource so that expected joint benefits will outweigh current costs" (Ostrom et al. 1999:281). The commons are honored by people whose livelihoods, way of life and cultural identity are formed through common resources (e.g., land and water) (Peterson 2011). With local knowledge of the environmental and resource conditions, people who depend on the resource for their livelihood are more likely to understand that monitoring the use of the resource provides long-term benefit (Ostrom et al. 1999). This is in contrast to private corporations, which usurp the commons from a distance through the laws of privatization and free market enterprise (Harvey 2005).

The dualistic perspective of nature and culture continues to dominate economic structures, policydecisions and public discourse today. A conflicting relationship is created when the water surrounding the bayou communities and the land they live upon is shared and used by different actors who do not share a common vision of what the resources that are produced from the waters and earth actually mean. For example, as the Chairman and Chief Executive Officer of the Apache Corporation, which owns land around the communities and is one of the world's biggest oil and gas exploration and production companies, stated, "Since its inception in 1954, Apache has been driven by a relentless pursuit of opportunity to profitably grow an independent oil and gas company for the long-term benefit of our shareholders" (Apache Corporation 2010:4). However, their shareholders are individual investors removed from the landscape, context and continued maintenance of the resources. Their goal is short-term, individual economic gain, as opposed to sustainable, shared long-term benefits. Such a scheme, in which the oil industry and State government have had a long-standing partnership, has helped turn coastal Louisiana into a sacrifice zone. 


\section{Land grabbing in a sacrifice zone}

Sacrifice zones are "...a place where human lives are valued less than the natural resources that can be extracted from the region" (Buckley and Allen 2011:171). For example, the energy produced in the Appalachian coalfields "...comes from a use of the land that treats it as disposable" (Purdy 2011:182). The coal industry in central Appalachia systematically prevents residents "...from developing community resources in ways outside the state's agenda - an agenda that systematically protects coal" and argues for strip mining in pursuit of private property rights (McNeil 2012:65, 69). Similarly, the protection of oil and private property, along with the drive for industrialization and economic gain helped turn coastal Louisiana into an energy sacrifice zone (Colten 2012; Martinez-Alier et al. 2014).

While the idea of the sacrifice zone and land grabbing are seen most distinctly in Louisiana through the oil industry, this was not the first private entity to lay claim to public land in Louisiana. Since the Spanish and French colonialists arrived, Louisiana's coastal wetlands have been "...perceived both as wastelands and as systems capable of endless regeneration and renewal" (Austin 2006:674). For example, in the late 1800s large tracts of cypress swamplands were passed into the private domain, placing the virgin cypress timber directly into the economic marketplace and leading to large-scale and rapid deforestation (Austin 2006).

In talking about the destruction caused by the oil companies, locals often pointed to corporate greed and power and lack of political will as the root problems. As one tribal leader told me:

They should've replaced the barrier islands a long time ago...Now, I can't say that they can't do it...They don't want to do it. So instead, they would rather sacrifice communities and say well, you know we did what we could do.

The idea of being sacrificed was repeated several times by others, such as one woman who had relocated after being flooded out from a hurricane described the land disappearing, "it's just going to be sacrificed. It always makes you figure you're just being sacrificed for bigger benefits."

Neoliberal policies, emphasizing free trade and privatization, that currently guide our economic and social system, encourage the idea of a sacrifice zone (Harvey 2005; McNeil 2012). Such policies played a major role in creating what Harvey dubbed accumulation by dispossession, which includes the commoditization and privatization of land and involves the appropriation of the non-human environment by the wealthy, ruling class, highlighting the loss of environmental, as well as social and economic rights (Harvey 2003:145; also Castree and Braun 1998; Foster 1999; Harvey 2006; Kovel 2007).

For example, pre-Hurricane Katrina social inequalities in New Orleans were maintained and reproduced after the storm through neoliberal housing policies and the tenets of "disaster capitalism" (Klein 2007). Two different communities emerged in New Orleans post-Katrina. One community was the "desolate, out-of-the-way trailer camps for low-income evacuees, built by Bechtel or Fluor subcontractors, administered by private security companies who patrolled the gravel lots" (Klein 2007:524). By contrast, the other type of community emerged in the wealthier areas, where residents had water and emergency generators within weeks after Katrina hit, people were treated in private hospitals and children attended new charter schools (Klein 2007:532). As Reed explained, "the people who were swept aside or simply overlooked in this catastrophe were the same ones who were already swept aside in a model of urban revitalization that...is predicated on their removal" (2008:148).

In the case of the oil and gas global production network, neoliberal capitalist policies have resulted in "frontier dispossession and reckless accumulation" (Watts 2012:458), in which oil states support petrocapitalism and the logic of oil extraction is a central component in "the making and breaking of community" (Watts 2004:199). For example, Nigeria's neoliberal policies, such as the Land Use Act, continued the colonial-based system of allowing multinational oil corporations to claim resources under the land as their own instead of the local landholders (Okonta and Douglas 2003). In siphoning over US\$30 billion worth of crude oil from Ogoniland in the Niger Delta, the multinational oil corporations conducted an ecological warfare that left the environment completely degraded in its wake. Cloaked in the guise of "resource politics," what is most notable about such circumstances is "the total invisibility of both 
transnational oil companies (which typically work in joint ventures with the state) and the specific forms of rule associated with petro-capitalism" (Watts 2003:5091).

In Louisiana, multinational oil corporations and private land developers, with the backing of the State, grabbed the tribes' lands during the first half of the $20^{\text {th }}$ century. Locals told me how the oil companies made people sign leases they could not read or understand, as most did not speak or read English, to lease their land for drilling. Furthermore, local residents explained that if no one is paying taxes on a property, the State could take over the mineral rights to sell to an oil corporation. This happened all over coastal Louisiana. For example, one person described to me how his family in Lafitte, just to the east of the three communities, had their property taken by the Louisiana Land and Exploration Company.

Similarly, once land disappears under water, the State takes it over and the submerged land can be sold off to private corporations. The tribes are thus blocked from restoring the land that is left, such as their sacred, ancestral mounds, because they would need to start restoration efforts in the water surrounding the land, which is now owned by private corporations. Furthermore, with their purchasing power and control over local resources, multinational oil corporations and private land developers have bought up vast quantities of dirt and land on higher ground just north of the communities, leaving the tribes with few options as their land becomes further inundated by saltwater.

The relationship between the oil industry and the State was most recently highlighted when the Southeast Louisiana Flood Protection Authority-East filed a lawsuit against 97 oil, gas and pipeline companies for "ravag[ing] Louisiana's coastal landscape" and demanding that the companies restore the damaged wetlands or pay for damages they caused that cannot be restored (Jones, Swanson, Huddell and Garrison, LLC 2013:3). The three members of the Authority board that voted against the resolution for the lawsuit were appointed by Louisiana Governor Bobby Jindal, who claimed the lawsuit was not in line with Louisiana's coastal restoration policy (Schleifstein 2013).

Places such as coastal Louisiana have become "the new geographies of domination" (Reid and Taylor 2010:11), within which increasingly vulnerable populations become further marginalized through the process of displacement.

\section{Multi-causal forced displacement}

Social science literature has documented the many negative consequences for the individuals, families and communities affected by development-caused forced displacement and resettlement (DFDR) over the past four decades (Cernea and Mathur 2008; De Wet 2006; Koenig 2009; Mahapatra 1999; OliverSmith 2009; Scudder 2005; Scudder and Colson 1982; Vine 2009). Social scientists have analyzed the impacts of DFDR on people's lives and livelihoods and the underlying drivers that shape the current development paradigm, which has a tunnel-vision focus on economic growth, perceives the world as an infinite resource to be used and de-couples humans from the environment (Maldonado 2012a).

The consequences of forced displacement, defined as "...the process through which population groups are compelled against their will to leave their habitat or/and productive activities and to seek alternative locations and modes of securing their living" (Cernea 2008:12), include, but are not limited to, marginalization, loss of resilience, livelihoods and traditional skills, health and education risks, break up of family and social groups and communities and the mental stress of living in a strange place (Cernea 2008; De Wet 2006; Downing 2002; Mahapatra 1999; Sapkota 2000; Scudder 2005).

Multiple elements - political, economic, cultural, social and environmental - often work together to lead to displacement. For example, it is not only the coexistence of dredging for pipelines, oil spills, hurricanes and other slow and rapid-onset hazards and disasters afflicting the three tribes. Rather, it is the social and political factors interconnected with these processes that have created the perfect storm of multicausal displacement.

The three communities have experienced different fluxes of people relocating over time. Some periods have seen greater numbers of people relocating, such as following Hurricane Andrew in 1992, Hurricanes Katrina and Rita in 2005 and Hurricanes Gustav and Ike in 2008. The change in population has been most extreme on Isle de Jean Charles. For example, as opposed to the 78 houses and approximately 325 people on the Isle in 2002 before Hurricane Lili, there are now about 25 houses and 70 people left. 
Forced displacement is more than just about physical relocation. It drastically impacts people's lives physically, economically, socially and culturally. When the environment people depend on for their livelihoods and way of life is drastically altered and degraded (Figure 4), they can experience the same stress and risks as those that have relocated. Some of the impacts experienced by residents of the three communities include health, livelihood and loss of sense of place.
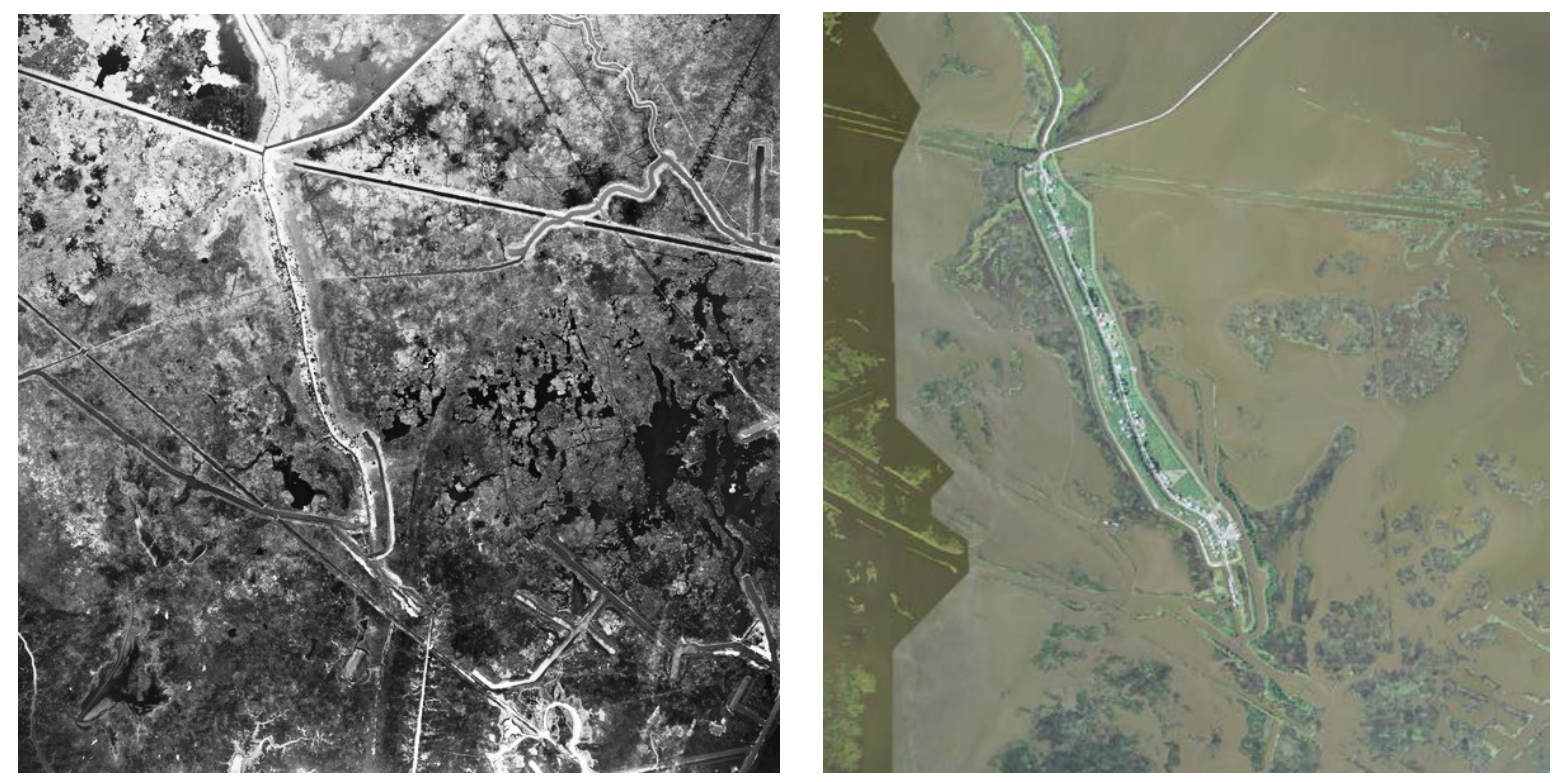

Figure 4: Isle de Jean Charles in 1963 and 2010. The island has shrunk from c. $16 \mathrm{~km}$ to 3.2 $\mathrm{km}$ in length, and is now $400 \mathrm{~m}$ across. Source: USGS.

\section{Health and livelihood impacts}

Community members talked about changes in their own and family members' health over the years, including soaring rates of diabetes, cancer and high blood pressure. The impacts being experienced are not merely coexisting illnesses, but rather the interconnectedness with health-threatening social conditions (Farmer 2003; Singer and Clair 2003). Decades-long industrial contamination, encroaching toxic industries, chemicals from dispersants, oil spills, including the 2010 BP Deepwater Horizon oil disaster, and poststorm debris continue to contaminate the communities' air, soil and water, creating severe health and livelihood impacts and a forced change in diet (Louisiana Workshop 2012; Maldonado et al. 2013). Furthermore, traditional means of dealing with illnesses are no longer available, as saltwater inundation has killed the medicinal plants and herbs.

Not only do many fear the contamination in their drinking water, but in their soil as well, in part because of the heavy metals that come with flooding and the encroaching oil industry. They can no longer be sure of what they are putting in their bodies. The contamination and pollution have caused what Singer described as "toxic frustration" (Singer 2011:158). People's subjective experience of living in a changing environment is embedded within their broader social experience of being economically, politically and socially marginalized (Auyero and Swistun 2009; Singer 2011). Previously, longevity was a part of their heritage, but now, "we are the sacrificed communities and our people are dying younger because of new diseases we never had before" (Louisiana Workshop 2012).

State regulations put in place because of the large-scale commercial fishing industry and to protect oil interests have contributed to people's economic and subsistence displacement (Harrison 2012). As one resident of Point-au-Chien described, "When we were growing up...if you wanted oysters in the wintertime...just get in the boat and go get some oysters. You can't do that now. If you don't have an oyster 
lease you can't go out there." Now, they have to lease oyster beds from the oil companies, major land developers and U.S. Fish and Wildlife Service.

Everyone once had gardens that provided a self-sustaining way of life. But the land they once planted was now either underwater (Figure 4), or the soil was so saturated with saltwater that it was difficult for plants to grow. Some community members described the loss of gardens and subsequent changes in diet as being one of the factors causing health impacts. When they ate from the land and waters, they shared with each other. But now they are forced to buy more food from the grocery store for their own families, so the sense of sharing has diminished, in addition to the economic burden of having to spend money on food they used to grow for free. Whereas before they had everything they needed where they were, they now have to seek food and materials elsewhere.

\section{Placelessness}

Living in a place-based community - where people's social, cultural and economic lives and livelihoods are carried out in a specific place - means that the losses people experience coincide with the changing landscape. As one resident of Isle de Jean Charles described in his digital story:

My home is this, my people is this right here. It's the place I've always known as home. This land has fed our people. It may not be much, but it is ours. Being Native there is a strong connection to the land; it gives to you and you give back to it. If a storm brought oil into our homes and the government said we couldn't go back, I couldn't put the impact into words. I still want to live here because I'm Native American, because I'm connected to the land. I'm going to live here as long as I can. I belong here.

Belonging to a place is about a relationship between a physical space and one's cultural identity (Cernea 2005; Kibreab 2000). People often expressed this connection through their feelings of mourning for a lost home, where the concept of "home" refers to the broader community, including the landscape, history, stories and traditions tied to a place. As one community leader described in discussing the concept of "home", "it's what our culture and heritage is all about, it's where we live, it's our family, our friends. It's everything about us. Home's not a house, home is your community."

For people who have spent their lives navigating coastal Louisiana's intricate web of waterways (Figure 5), as their seascape and landscape have changed, the land loss is not just physical but impacts their sense of place, belonging and local knowledge. An elder from Isle de Jean Charles described to me how they used to take pirogues (small, dugout boats) through the marsh between the Isle and Pointe-au-Chien and the places they used to go, but "[n]ow it's hard to distinguish where those places are." For place-based communities, when one's landscape is drastically altered, "the sense of betrayal and disorientation is acute," as the known environment and "communal pattern of identity" breaks apart (Tall 1993:91).

While those who have relocated can experience the stress that comes from being uprooted from their lands and living in a new place, those still in-place but living in unfamiliar surroundings can experience this stress as well. What was once so known becomes unfamiliar, leading to a sense of "solastalgia," which is "the distress that is produced by environmental change impacting on people while they are directly connected to their home environment" (Albrecht et al. 2007). Jackson (2011) found that Aamjiwnaang residents in Ontario, Canada, whose community was experiencing extreme levels of air pollution due to petroleum-related chemicals were suffering from anxiety due to the dangerous smells invading their community. As opposed to the positive sense of place once reinforced by the smell of the landscape, the toxicscape they now suffered created a sense of alienation from their homelands, or what Jackson dubbed "dysplacement" (2011).

Much like the profound shift in perceptual experience due to the toxic smell in Aamjiwnaang residents' daily lives, coastal Louisiana's residents experienced this same sense of alienation. For example, as one woman who had relocated from Grand Caillou/Dulac to a nearby community further north expressed to me, "There's this certain smell in the morning of the dew on the leaves...and you just take in a deep breath and you miss that...I don't smell those smells here. I wake up in the morning and go outside and take a deep breath, it's just not here." Residents in-place also have experiences of acute alienation invoked by 
the changing landscape. For example, as I passed through a wide-open canal (Figure 3) on a boat with a resident of Pointe-au-Chien, she described how when she was growing up her family would take the boat down the bayou to visit her grandparents and the bayou was so narrow she could pull the grass along either side of the boat with her hands. She talked about the large swaths of forest that covered both sides of the bayou. Looking out at the ghost forests of oak trees that now overwhelmed the landscape, she pointed out where her grandparents had lived, which was now dying marsh falling into the open canal. Describing the scene in her digital story she wrote, "It was pretty here before. Now all we have are skeletons."

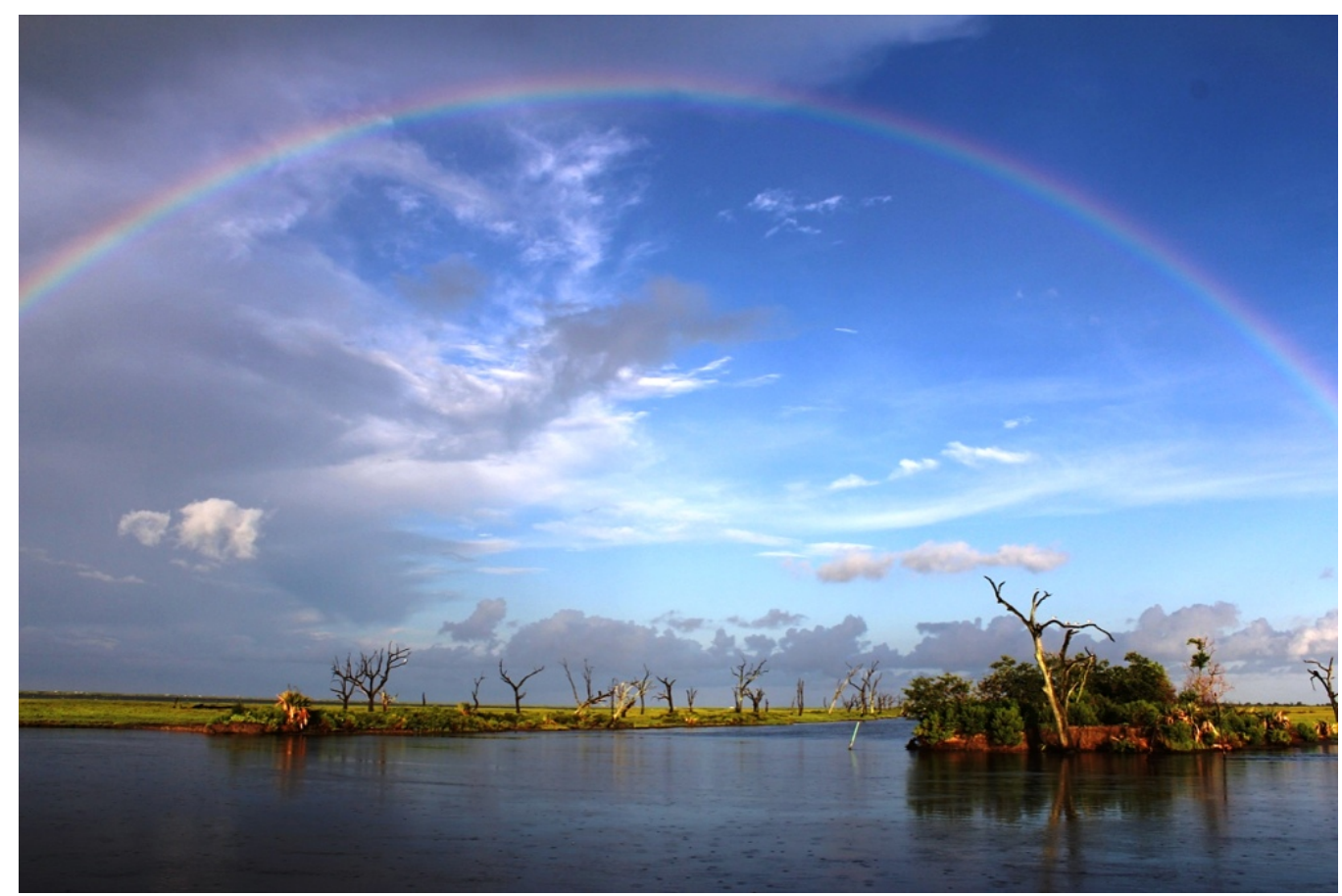

Figure 5: The bayou landscape. Source: Maldonado, 2012.

Whereas local residents once lived together in close-knit communities, now many people described their community as scattered. For example, with so few households left on the Isle, one resident said, "it's like the skeleton of the body." The physical changes in the landscape, such as erosion and increased flooding, create a sense of uncertainty of whether or not their homelands will remain above the rising tide. This raises concern about what the environmental changes mean for their culture, livelihoods and sense of place. Despite the social, cultural and livelihood impacts being experienced, the political decisions of whether or not to mitigate the environmental damages are embedded solely within an economic argument based on cost-benefit analyses (CBA).

\section{Cost-benefit analysis: determining the greater common good}

The three tribal communities have thus far been mostly left out of government-led restoration and mitigation efforts. For example, Isle de Jean Charles was included in the USACE's original Morganza-tothe-Gulf of Mexico Hurricane Protection system plan. However, the community was cut out of the plan in 1998 because the government authorities claimed it was not cost-efficient to include them. The USACE decided it was more feasible to relocate the people from Isle de Jean Charles than include them in the levee protection system. However, without understanding the local and internal politics, the relocation plan fell apart.

It appears that the communities' exclusion from State-led mitigation and restoration efforts will continue as funds from the Resources and Ecosystems Sustainability, Tourist Opportunities and Revived Economies of the Gulf Coast States Act (RESTORE Act) are distributed. The RESTORE Act requires 80\% 
of the Clean Water Act penalties paid by the parties responsible for the 2010 BP Deepwater Horizon disaster to go towards Gulf Coast restoration. However, the State of Louisiana has dedicated all RESTORE Act funds to be spent on projects contained within the 2012 Louisiana Master Plan for a Sustainable Coast, which has mostly left out the three tribal communities.

The Gulf Coast Ecosystem Restoration Council "recognizes the value of tribal input in the region's restoration activities" (Gulf Coast Ecosystem Restoration Council 2013:1). However, the plan to restore the Gulf Coast pointed to Presidential Executive Order 13554, which stated that the Gulf Coast Ecosystem Restoration Task Force may include representatives from tribes affected by the BP Deepwater Horizon disaster. But the Executive Order defined affected tribes as "any Indian tribe, band, nation, pueblo, village, or community that the Secretary of the Interior acknowledges to exist as an Indian tribe as defined in the Federally Recognized Tribe List Act of 1994 (25 U.S.C. 479a(2)), physically located in a Gulf State" (White House 2010). This discounts the three tribes because, despite the Bureau of Indian Affairs recognizing their Indian ancestry (Bureau of Indian Affairs 2008), they have thus far been denied tribal federal recognition. This is in part because of historical injustices, such as being forced into isolation and lack of formal treaties with white settlers, making it exceedingly difficult to provide written evidence of a sustained political authority and descent from an historical tribe (Miller 2004). In June 2004, the tribes were officially recognized as Indian tribes by the State of Louisiana. But without federal recognition, they lack government support offered to federally-recognized tribes.

Looking at the map of 2050 in the 2012 Louisiana Master Plan, without restoration and flood protection measures, all of the land in and around the tribal communities will be gone. CBA used to make coastal restoration decisions do not account for what is actually being lost, such as social services and structures, entire cultures, livelihoods and sacred places. CBA does not include the costs of what it means when fishing families are moved inland, local knowledge is lost and mental stress results from being removed from the only way of life one has ever known. While some social costs can be quantified, such as loss of jobs, others are more difficult to measure, such as loss of livelihood and the meaning of a cultural site. Legitimizing the injury done to some through claims of a more universal benefit, CBA is deficient, as it accounts for neither the distribution of costs and benefits nor important non-market social and cultural factors, such as people's identity, beliefs and traditions (Cernea 2000, 2008; Fernandes 2008; Mayo 2010; Oliver-Smith 2010). If all of these costs were actually accounted for, the real figures would show that when projects are determined based on CBA, the benefits do not outweigh the costs.

These decisions, which are legitimized by government authorities, need to be critically scrutinized, as they dictate and determine who is being sacrificed for the supposed greater common good (Roy 1999). By assessing what restoration efforts are needed and implementing such plans based on CBA, Westman, in an analysis of impact assessment documents for Canada's Alberta tar sands, found that at "...the root of these discussions lie differentials in power: power to tell the story of the future and then to enact it" (2013:112). The loss of place - placelessness - is not a tangible element that can be quantified and compensated. As more land disappears the question becomes: where do the communities go when everything around them is gone?

\section{The Catch-22 of relocation}

During a story circle, I asked a few people from Isle de Jean Charles, some of whom had relocated and some still in-place, if they thought people would be able to stay on the Isle or if the community would need to relocate. Talking about restoration plans for the area, predominantly based around Houma, the industrial hub about thirty miles north of the Isle, they said:

A Well, I don't think they can save the island.

B They don't want to save the island, they could if they wanted to...

A The levee's gonna pass south of Houma, you know where the Ranch Road is, the levee's gonna be right south of there. They started on it already.

B So they're drowning everything below.

A South. 
B They're drowning everything south of that.

C South of Houma, yeah.

B I would call that discrimination.

The Louisiana Coastal Master Plan had the option of voluntary relocation through the non-structural program, but only for individual households wanting to relocate (CPRA 2012). According to the Coastal Protection and Restoration Authority of Louisiana (CPRA), relocation as a community was not yet included in the Plan, but there are federal programs that could assist if communities were in harm's way. The Master Plan projected that $3-5 \%$ of people along the coast will need to be relocated. However, even these numbers are already outdated, as new predictions by NOAA have southeast Louisiana experiencing the highest rate of relative sea level rise worldwide, with an additional 4.3 feet of water $(131 \mathrm{~cm})$ rising by the end of this century (Marshall 2013).

Some of the tribal leaders pointed out that without a plan to relocate them as communities, they would lose their culture and heritage and their chances for federal recognition would be gone. As one of the leaders called out during her two minutes to speak at a public hearing for the draft Master Plan:

We are presented with a plan that contains no equitable balance...the only option our people have had is to relocate... doing so individually will annihilate the beauty of what it is to be an American Indian resident on the Gulf Coast.

The involvement of government in community-led relocation efforts is a sensitive undertaking. There is a very real fear among communities that governments are using environmental change, such as sea level rise due to climate change, as an excuse to move people out of harm's way to develop desired coastlines for tourists and external wealthy elites. For example, the Maldives' government saw the land along the beach where local villagers lived as being more profitable if put to use for tourism, instead of the fishing that only maintained the lives of the local villagers (Klein 2007; Reed 2008). The Maldives' government announced after the 2004 tsunami hit that residents needed to move to one of five islands designated as safe zones, thus clearing entire areas for tourism (Klein 2007:505, 507). The class warfare that took place post-tsunami illustrated how the non-human environment played a key role in maintaining pre-existing inequalities and reproduced these inequalities by pushing low-income communities onto marginal lands and excluding them from the economic sphere. Several residents from the bayou communities voiced a similar fear. For example, when I asked a young man who had relocated from Dulac about ten miles north to southern Houma if he felt other impacts besides storms and flooding when he was living in Dulac, he responded, "Well, I guess you could say our rights. Because they don't wanna recognize us because this is a shipping port or a shipping lane for the oil field company and if they do that, then we don't make money off of them passing through."

While the Pointe-au-Chien tribe, with some storm protection and land left, is actively working to stay in place as long as it can, leaders from Isle de Jean Charles are facing an immediate need to relocate the community, and Grand Caillou/Dulac is now facing this reality as well. The leaders of Isle de Jean Charles were concerned that because tribal members are so scattered the tribe will no longer exist if they are geographically separated, so they want to find land where people can move together. They are working to relocate together those who have scattered and those who would like a communal safe haven, while still working to save their ancestral land. They are looking not just for community and cultural restoration but also for traditional livelihood development to once again be a self-sustaining community.

Over the years, however, they ran into countless policy obstacles and the practical challenges of community-led relocation, such as the plans that fell apart through the USACE. There is no Federal government agency mandated to manage communities' relocation efforts and there are no funds for proactively moving an entire community (Bronen 2011; Maldonado et al. 2013; NCADAC 2013). Despite the social science knowledge that has been generated, there is still a severe lack of effective policies to support communities that suffer from the injustice of forced displacement.

While some communities such as Grand Caillou/Dulac do not need to relocate yet, their leaders would like to have a plan in place so they could be prepared when the time comes. It is a tricky position for 
the leaders, the challenge of working in two realities. On one hand, they do not want to get to the point of realizing the need to relocate too late, as relocation plans take many years to effectively develop and implement. On the other hand, with limited resources and time, there needs to also be a focus on saving what is left and maintaining the community in-place as long as possible. Thus, the leaders find themselves in a Catch-22, trying to do what they feel is best for their communities, but also risk losing credibility with those who do not want to relocate (Scudder 2005:26-7).

People relocating and loss of cultural practices, traditions and a way of life is not just happening in these communities, but throughout coastal Louisiana. As a representative of the Barataria Terrebonne National Estuary Program explained to me:

People are moving away. Further up and further out, out of state. And that's the one thing I fear most because that's the culture, everything's about that. The fact that we've kept these people here generation after generation and we're losing that. Isle de Jean Charles is just a symptom of what's happening everywhere.

Descendants of other population groups, such as the Acadians, Isleños (Canary Islanders) and African and Caribbean slaves who also sought refuge in the area to escape persecution are undergoing similar experiences to that of the tribal communities.

Local, state, tribal and national government agencies do not currently have the capacity to support relocation processes, and the U.S. does not have an institutional framework to support the relocation of entire communities (Bennett et al. 2013; Bronen 2011). The lack of governance mechanisms or frameworks to support communities facing displacement intensifies the negative economic, social, cultural, and psychological and health impacts being experienced (Bennett et al. 2013; Bronen 2011:360; Maldonado et al. 2013). A relocation framework that takes a justice- and rights-based approach is needed, one that demands the recognition of the social and cultural components of displacement (Bronen 2011). As Archbishop Desmond Tutu said, "No community with a sense of justice, compassion or respect for basic human rights should accept the current pattern of adaptation"; instead, we need to avoid continuing into "a world of 'adaptation apartheid"' (2007/2008:166).

\section{Multiple knowledges informing adaption and relocation}

A rights-based approach to relocation that includes multiple forms of knowledge requires understanding people's social and cultural values and worldviews, which demands an iterative, participatory process between project implementers and local populations (Maldonado 2012a; Stammler 2007). Most significantly, this calls for community-led relocation in which the communities actively lead efforts with support as needed not only to relocate, but also create a plan for enhanced community development. This requires improved institutional development to support respectful relationships between tribal communities, government authorities and other involved parties to significantly include the communities' voices and input in all decisions (Farbotko and Lazrus 2012; Maldonado et al. 2013; Whyte 2013). In other words, a democratization of the adaptation process is needed that includes more equitable distribution of knowledge sharing and integration, public participation and different ways of knowing in decision-making.

Decolonization of research and policy-formation could be done through the incorporation of multiple knowledges - traditional ecological knowledges and knowledges of native and non-native scientists. If indeed wisdom does sit in places (Basso 1996), including "indigenuity" and multi-generational traditional knowledges, their incorporation into adaptation planning and decision-making would help to democratize the process (Wildcat 2009, 2013). Understanding different forms of knowledge and worldviews, especially those pertaining to nature-culture relations, sheds light on how power is linked to concerns of everyday life (Wolf 1999), which in turn helps to reveal the underlying structures of vulnerability. This would help us move beyond the frameworks that see vulnerability as static, objective and quantifiable, and instead analyze vulnerability as a process that is subjective, qualitative, proportional, contextual and multi-scalar (Kelman 2009). A systems-thinking approach to adaptation would help shift the economic-based framework for adaptation towards a people-centered framework that focuses on human 
rights, local participation, input and decision-making, and highlights the social, political, and economic inequalities created under our current system (Maldonado 2012b).

Combining different forms of knowledge can be very difficult, however, as the different frameworks and assumptions might not share the same vision for the future or agree upon the current reality (Westman 2013). We need to be careful of how local knowledge is understood and incorporated. For example, as Cruikshank explained, "codified in government reports, information formulated as [traditional ecological knowledge] tends to reify and reinforce a Western dualism—prying nature from culture-that local narratives challenge in the first place" (2001:389).

Communities should be empowered to make their own decisions on whether relocation is a necessary adaptation strategy or not (Hugo 2011), which is especially important given the long history of indigenous experiences with forced displacement and relocation (Marino 2012). Not wanting to reproduce the social, political and economic structures that have left communities vulnerable to environmental change, planning for relocation should not be done "at the expense of in situ disaster mitigation and climate adaptation" (Lazrus 2009:37). However, there is a pressing need for flexibility in the existing governance structures to enable agencies to support communities if they deem that in-situ adaptation is no longer viable and they need to relocate (Bronen 2011; Shearer 2012).

Without such flexibility, relocation efforts are often thwarted if issues arise with one agency (Shearer 2012), such as occurred with Isle de Jean Charles and the USACE. Existing governance structures are insufficient for the long-term environmental changes communities face and the need for pro-active measures. For example, agencies such as the Federal Emergency Management Agency (FEMA) "...are primarily triggered to action only after 'institutionally recognized' disasters, often preventing them from taking action on earlier signals of concern and danger" (Shearer 2012:178). Furthermore, focused on postdisaster relief and emergency assistance, agencies such as FEMA are not mandated to address long-term environmental changes leading to relocation (Bronen 2011), as is now occurring in coastal Louisiana.

Partnerships between local leaders, residents and decision-makers need to be formed, incorporating policy-makers at the local, state, national and international levels to effectively address not just the environmental concerns, but the social, political and economic structures and frameworks that have shaped and created the environmental impacts communities experience (Austin 2004). In considering new governance structures, an evaluation process needs to be put in place to help ensure the rights of those who are relocating. Ensuring that all created policies and practices are rooted in a human rights framework would enhance the protection of indigenous peoples' rights to self-determination and preservation of their social and cultural worlds (Bronen 2011; Maldonado et al. 2013). Such a framework could serve as a model for all indigenous and non-indigenous communities alike.

\section{References}

Albrecht, G., G. Maree Sartore, L. Connor, N. Higginbotham, S. Freeman, B. Kelly, H. Stain, A. Tonna and G. Pollard. 2007. Solastalgia: the distress caused by environmental change. The Royal Australian and New Zealand College of Psychiatrists 15: S95-S98.

Apache Corporation. 2010. More than meets the eye: summary annual report 2010. Available online at http://www.apachecorp.com/Resources/Upload/file/downloads/Apache_AR_2010.pdf (last accessed 23/7/ 2013).

Austin, D. 2006. Cultural exploitation, land loss and hurricanes: a recipe for disaster. American Anthropologist 108(4): 671-691.

Austin, D. 2004. Partnerships, not projects! Improving the environment through collaborative research and action. Human Organization 63(4): 419-430.

Auyero, J. and D.A. Swistun. 2009. Flammable: environmental suffering in an Argentine shantytown. Oxford: Oxford University Press.

Barry, J. 1999. Environment and social theory. London: Routledge.

Barry, J.M. 1997. Rising tide: the great Mississippi flood of 1927 and how it changed America. New York: Simon and Schuster Paperbacks. 
Basso, K.H., 1996. Wisdom sits in places: landscape and language among the Western Apache. Albuquerque: University of New Mexico Press.

Bennett, T.M., N.G. Maynard, P. Cochran, B. Gough, K. Lynn, G. Voggesser and S. Wotkyns. 2013. Impacts of climate change on tribal, indigenous, and native lands and resources. In NCADAC [National Climate Assessment and Development Advisory Committee]. Draft National Climate Assessment. Pp.441-468. Available online at http://ncadac.globalchange.gov (last accessed 27/8/2013).

Bronen, R. 2011. Climate-induced community relocations: creating an adaptive governance framework based in human rights doctrine. New York University Review of Law and Social Change. 35: 356406.

Buckley, G.L. and A. Allen. 2011. Stories about mountaintop removal in the Appalachian coalfields. In M. Morrone and G.L. Buckley (eds.) Mountains of injustice: social and environmental justice in Appalachia. Athens, OH: Ohio University Press. Pp. 161-180.

Bureau of Indian Affairs. 2008. Summary under the criteria and evidence for amended proposed finding against federal acknowledgment of the Biloxi, Chitimacha Confederation of Muskogees, Inc. Washington, DC: The Office of the Assistant Secretary - Indian Affairs (AS-IA), Department of the Interior.

Burkett, V. and M. Davidson (eds.). 2012. Coastal impacts, adaptation and vulnerability: a technical input to the 2012 national climate assessment. Cooperative Report to the 2013 National Climate Assessment.

Button, G. and A. Oliver-Smith. 2008. Disaster, displacement and employment: distortion of labor markets during post-Katrina reconstruction. In N. Gunewardena and M. Schuller (eds.) Capitalizing on catastrophe: neoliberal strategies in disaster reconstruction. Lanham, MD: Altamira Press. Pp. 123145.

Button G.V. and K. Peterson. 2009. Participatory action research: community partnership with social and physical scientists. In S.A. Crate and M. Nuttall (eds.) Anthropology and climate change: from encounters to actions. Walnut Creek: Left Coast Press. Pp 327-340.

Castree, N. and B. Braun. 1998. The construction of nature and the nature of construction: analytical and political tools for building survivable futures. In B. Braun and N. Castree (eds.) Remaking reality: Nature at the millennium. London: Routledge. Pp. 2-41.

Cernea, M.M. 2008. The impoverishment risks and reconstruction model: resettlement and benefit-sharing. Manila: Asian Development Bank.

Cernea, M.M. 2005. Concept and method: applying the IRR model in Africa to resettlement and poverty. In I. Ohta and Y. Gebre (eds.) Displacement risks in Africa. Japan: Kyoto University Press. Pp. 195239.

Cernea, M.M. 2000 Risks, safeguards and reconstruction: a model for population displacement and resettlement. Economic and Political Weekly 35(41): 3659-3678.

Cernea, M.M. and H.M. Mathur. 2008. Can compensation prevent impoverishment? Reforming resettlement through investments and benefit-sharing. Oxford: Oxford University Press.

Coastal Louisiana Ecosystem Assessment and Restoration [CLEAR]. 2006. Reducing flood damage in coastal Louisiana: communities, culture and commerce. Availabe online at http://www.clear.lsu.edu (last accessed 27/11/2013).

Coastal Protection and Restoration Authority of Louisiana [CPRA]. 2012. Louisiana's comprehensive master plan for a sustainable coast. Baton Rouge, LA. Available online at http://www.lacpra.org/assets/docs/2012\%20Master\%20Plan/Final\%20Plan/2012\%20Coastal\%20Ma ster\%20Plan.pdf (last accessed 13/8/2013).

Colten, C.E. 2012. An incomplete solution: oil and water in Louisiana. The Journal of American History June: 91-99.

Couvillion, B.A., J.A. Barras, G.D. Steyer, W. Sleavin, M. Fischer, H. Beck, N. Trahan, B. Griffin, and D. Heckman. 2011. Land area change in coastal Louisiana from 1932 to 2010: U.S. Geological Survey Scientific Investigations Map 3164. 
Cruikshank, J. 2001. Glaciers and climate change: perspectives from oral tradition. Arctic 54(4): 377-393.

De Wet, C. (ed.) 2006. Development-induced displacement: problems, policies and people. New York: Berghahn Books.

Downing, T.E. 2002. Avoiding new poverty: mining-induced displacement and resettlement. Available online at http://www.iied.org/mmsd/mmsd_pdfs/058_downing.pdf. (last accessed '13).

Escobar, A. 1996. Constructing nature: elements for a poststructuralist political ecology. In R. Peet and M.J. Watts (eds.) Liberation ecologies: environment, development, social movements. London: Routledge. Pp. 46-68.

Farbotko, C. and H. Lazrus. 2012. The first climate refugees? Contesting global narratives of climate change in Tuvalu. Global Environmental Change 22: 382-390.

Farmer, P. 2003. Pathologies of power: health, human rights, and the new war on the poor. Berkeley: University of California Press.

Fernandes, W. 2008. India's forced displacement policy and practice: is compensation up to its functions? In M.M. Cernea and H.M. Mathur (eds.) Can compensation prevent impoverishment? reforming resettlement through investments and benefit-sharing. London, New Delhi: Oxford University Press. Pp. 180-207.

Foster, J.B. 1999 The vulnerable planet: a short economic history of the environment. New York: Monthly Review Press.

Freudenberg, W.R., R. Gramling, S. Laska and K.T. Erikson. 2009. Catastrophe in the making: the engineering of Katrina and the disasters of tomorrow. Washington DC: Island Press.

Gulf Coast Ecosystem Restoration Council. 2013. Draft Initial Comprehensive Plan: Restoring the Gulf Coast's Ecosystem and Economy. Available online at (last accessed 27/11/2013).

Haila, Y. 1999 The north as/and the other: ecology, domination, solidarity. In F. Fischer and M.A. Hajer, (eds.) Living with nature: environmental politics as cultural discourse. Oxford: Oxford University Press. Pp. 42-57.

Hardin, G. 1968. The tragedy of the commons. Science 162: 1243-1248.

Harrison, J.A. 2012. Buoyancy on the bayou: shrimpers face the rising tide of globalization. Ithaca, NY: Cornell University Press.

Harvey, D. 2003. The new imperialism. Oxford: Oxford University Press.

Harvey, D. 2005. A brief history of neoliberalism. Oxford: Oxford University Press.

Harvey, D. 2006. Spaces of global capitalism: towards a theory of uneven geographical development. London: Verso.

Hewitt, K. 1983. Interpretations of calamity. Winchester, MA: Allen and Unwin.

Hilhorst, D. and G. Bankoff. 2004. Introduction: Mapping Vulnerability. In G. Bankoff, G. Franks and D. Hilhorst (eds.) Mapping vulnerability: disasters, development and people. London: Earthscan. Pp. 1-9.

Hugo, G. 2011. Lessons from past forced resettlement for climate change migration. In E. Piguet, A. Pécoud and P. de Guchteneire (eds.) Migration and climate change. Cambridge: Cambridge University Press. Pp. 260-288.

IPCC [Intergovernmental Panel on Climate Change]. 2007. Fourth assessment report: impacts, adaptation and vulnerability. Available online at www.ipcc.ch/ipccreports/assessments-reports.htm (last accessed 7/8/2013).

Jackson, D.D. 2011. Scents of place: The dysplacement of a First Nations community in Canada. American Anthropologist. 113(4): 606-618.

Jones, Swanson, Huddell and Garrison, LLC. 2013. Petition for damages and injunctive relief. Filed July 24, 2013, Civil District Court for the Parish of Orleans, State of Louisiana. Available online at http://jonesswanson.com/wp-content/uploads/2013/07/Petition-for-Damages-and-Injunctive-Reliefwith-Exhibits-A-G.pdf (last accessed 10/12/2013).

Karl, T.R., J.M. Melillo and T.C. Peterson (eds.) 2009. Global climate change impacts in the United States: a state of knowledge report from the US Global Change Research Program. Washington, DC. 
Kelman, I. 2009 Understanding vulnerability to understand disasters. Available online at http://www.islandvulnerability.org/docs/vulnres.pdf (last accessed 3/12/2013).

Kibreab, G. 2000. Common property resources and resettlement. In M.M. Cernea and C. McDowell (eds.) Risks and reconstruction: experiences of resettlers and refugees. Washington, DC: The World Bank.

Klein, N. 2007. The shock doctrine: the rise of disaster capitalism. New York: Picador.

Koenig, D. 2009. Urban relocation and resettlement: distinctive problems, distinctive opportunities. In A. Oliver-Smith (ed.) Development and dispossession: the crisis of forced displacement and resettlement. Santa Fe, New Mexico: School for Advanced Research Press. Pp. 119-140.

Kovel, J. 2007. The enemy of nature: the end of capitalism or the end of the world. Boston: Zed Books.

Kütting, G. 2004 Globalization and the environment: greening global political economy. Albany, NY: State University of New York Press.

Laska, S., G. Wooddell, R. Hagelman, R. Grambling and M. Teets-Farris. 2005. At risk: the human, community, and infrastructure resources of Coastal Louisiana. Journal of Coastal Research 44: 90111.

Lazrus, H. 2009. Perspectives on vulnerability to climate change and migration in Tuvalu. In A. OliverSmith and X. Shen (eds.) Linking environmental change, migration and social vulnerability. Hohenkammer, Germany: UNU Institute for Environment and Human Security. Pp. 32-41.

Louisiana Workshop. 2012. Stories of change: coastal Louisiana tribal communities' experiences of a transforming environment. Input to the National Climate Assessment. Participating tribes: Grand Bayou Village, Grand Caillou/Dulac Band of the Biloxi-Chitimacha Confederation of Muskogees, Isle de Jean Charles Band of the Biloxi-Chitimacha Confederation of Muskogees, Pointe-au-Chien Indian Tribe. J.K. Maldonado (ed.)

Mahapatra, L.K. 1999. Resettlement, impoverishment and reconstruction in India: development for the deprived. New Delhi: Vikas Publishing House.

Maldonado, J.K. 2012a. A new path forward: researching and reflecting on forced displacement and resettlement. Journal of Refugee Studies 25(2): 193-220.

Maldonado, J.K. 2012b. Climate change and displacement: human rights and local knowledge as guiding principles for new policy initiatives. In M. Hamza and C. Corendea (eds.) Climate change and fragile states: rethinking adaptation. SOURCE Publication Series of UNU-EHS No. 16/2012. Pp. 77-93.

Maldonado, J.K., C. Shearer, R. Bronen, K. Peterson and H. Lazrus. 2013. The impact of climate change on tribal communities in the US: displacement, relocation, and human rights. Climatic Change 120(3): 601-614.

Marino, E. 2012. The long history of environmental migration: assessing vulnerability construction and obstacles to successful relocation in Shishmaref, Alaska. Global Environmental Change 22(2): 374381.

Marshall, B. 2013. New research: Louisiana coast faces highest rate of sea-level rise worldwide. The Lens. February 21.

Martinez-Alier J., Anguelovski I., Bond P., Del Bene D., Demaria F., Gerber J.-F., Greyl L., Haas W., Healy H., Marín-Burgos V., Ojo G., Porto M., Rijnhout L., Rodríguez-Labajos B., Spangenberg J., Temper L., Warlenius R. and I. Yánez. 2014. Between activism and science: grassroots concepts for sustainability coined by Environmental Justice Organizations. Journal of Political Ecology 21: 1960.

Marx, K. 1994[1888] The communist manifesto; preface to a contribution to the critique of political economy; capital, volume one. In L.H. Simon (ed.) Karl Marx: Selected writings. Indianapolis, IN: Hackett Publishing. Pp. 209-300.

Mayo III, R.J. 2010. Democracy and environmental decision-making: a review and analysis of the theoretical and empirical relationships. Masters Thesis. Syracuse, USA: State University of New York. 
McLean, K.G., A. Ramos-Castillo, T. Gross, S. Johnston, M. Vierros, R. Noa. 2009. Report of the indigenous peoples' global summit on climate change. 20-24 April 2009, Anchorage, Alaska. United Nations University-Traditional Knowledge Initiative, Darwin, Australia.

McNeil, B.T. 2012. Combating mountaintop removal: new directions in the fight against big coal. Urbana, Illinois: University of Illinois Press.

Miller, M. 2004. Forgotten tribes: unrecognized Indians and the federal acknowledgment process. Lincoln: University of Nebraska Press.

Morris, C. 2012. The big muddy: an environmental history of the Mississippi and its peoples from Hernando de Soto to Hurricane Katrina. Oxford: Oxford University Press.

NCADAC [National Climate Assessment and Development Advisory Committee]. 2013. Draft national climate assessment. Available online at http://ncadac.globalchange.gov (last accessed 27/8/13).

Newcomb, S. 1992. Five hundred years of injustice: the legacy of fifteenth century religious prejudice. Available online at http://www.wmktradio.com/files/Five\%20Hundred\%20Years\%20of\%20Injustice.pdf (last accessed 28/8/13).

NOAA [National Oceanic and Atmospheric Administration]. 2013. Underwater: land loss in coastal Louisiana since 1932. Available online at http://www.climate.gov/news-features/featuredimages/underwater-land-loss-coastal-louisiana-1932 (last accessed 2411/13).

NOAA [National Oceanic and Atmospheric Administration]. Global sea level rise scenarios for the United States national climate assessment. NOAA Technical Report OAR CPO-1. 2012.

Okonta, I. and O. Douglas. 2003. Where vultures feast: shell, human rights, and oil in the Niger Delta. London: Verso.

Oliver-Smith, A. 2010. Defying displacement: grassroots resistance and the critique of development. Austin: University of Texas Press.

Oliver-Smith, A. (ed.) 2009. Development and dispossession: the crisis of forced displacement andresettlement. Santa Fe, New Mexico: School for Advanced Research Press.

Oliver-Smith, A. 2004. Theorizing vulnerability in a globalized world: a political ecological perspective. In G. Bankoff, G. Franks and D. Hilhorst (eds). Mapping vulnerability: disasters, development and people. London: Earthscan. Pp. 10-25.

Oliver-Smith, A. 1999 Peru's five-hundred-year earthquake: vulnerability in historical context. In A. Oliver-Smith and S.M. Hoffman (eds.) The angry earth: disaster in anthropological perspective. New York: Routledge. Pp. 74-88.

Ostrom, E., J. Burger, C.B. Field, R.B. Norgaard and D. Policansky 1999. Revisiting the commons: local lessons, global challenges. Science 284:278-282.

Peet, R. and M.J. Watts (eds.) 1996 Liberation ecologies: environment, development, social movements. London: Routledge. Ch1,2

Peterson, K.J. 2011. Transforming researchers and practitioners: the unanticipated consequences (significance) of participatory action research (PAR). Ph.D. dissertation. New Orleans, LA: University of New Orleans.

Purdy, J.S. 2011. Afterword: an American sacrifice zone. In M. Morrone and G.L. Buckley (eds.) Mountains of injustice: social and environmental justice in Appalachia. Athens, OH: Ohio University Press. Pp. 181-184.

Quarantelli, E.L. (ed.) 1998. What is a disaster? A dozen perspectives on the question. New York: Routledge.

Rabalais, N.R., R.E. Turner, D. Justic, Q. Dortch, and W.J. Wiseman Jr. 1999. Characterization of Hypoxia: Topic 1 Report for the Integrated Assessment of Hypoxia in the Gulf of Mexico. NOAA Coastal Ocean Program Decision Analysis Series No. 15. U.S. Department of Commerce, National Oceanic and Atmospheric Administration. 
Reed, A. 2008. Class inequality, liberal bad faith, and neoliberalism: the true disaster of Katrina. In N. Gunewardena and M. Schuller (eds.) Capitalizing on catastrophe: neoliberal strategies in disaster reconstruction. Lanham, MD: Altamira Press. Pp. 147-154.

Reid, H. and B. Taylor. 2010. Recovering the commons: democracy, place, and global justice. Urbana, IL: University of Chicago Press.

Rising Voices Workshop. 2013. The rising voices of indigenous people in weather and climate science workshop. Indigenous Peoples Climate Change Working Group and National Center for Atmospheric Research, Boulder, CO. July 1-2.

Roy, A. 1999. The cost of living. New York: The Modern Library.

Sapkota, N. 2000. Using the risks and reconstruction model in resettlement planning: Kali Gandaki Dam, Nepal. The Eastern Anthropologist 53: 1-2.

Schleifstein, M. 2013. East Bank levee authority votes to reaffirm wetlands damage lawsuit against energy companies. The Times-Picayune. December 5. Available online at http://www.nola.com/environment/index.ssf/2013/12/east_bank_levee_authority_vote.html_ (last accessed 10/12/13).

Scudder, T. 2005. The future of large dams: dealing with social, environmental, institutional and political costs. London: Earthscan.

Scudder, T. and E. Colson 1982. From welfare to development: a conceptual framework for the analysis of dislocated people. In A. Hansen and A. Oliver-Smith (eds.) Involuntary migration and resettlement: the problems and responses of dislocated people. Boulder, Colorado: Westview Press.

Shearer, C. 2012. The political ecology of climate adaptation assistance: Alaska natives, displacement, and relocation. Journal of Political Ecology 19: 174-183.

Singer, M. 2011. Down cancer alley: the lived experience of health and environmental suffering in Louisiana's chemical corridor. Medical Anthropology Quarterly 25(2): 141-163.

Singer, M. and S. Clair, 2003. Syndemics and public health: reconceptualizing disease in bio-social context. Medical Anthropology Quarterly 17(4): 423-441.

Stammler, F. 2007. Relocation histories and attachment to place in Russia's gas capital: field impressions. Available online at http://www.alaska.edu/move/result/innocom/ (last accessed 29/7/13).

Stonich, S.C. and B.R. DeWalt. 2006. The political ecology of deforestation in Honduras. In N. Haenn and R. Wilk (eds.) The environment in anthropology: a reader in ecology, culture and sustainable living. New York: New York University Press. Pp. 284-301.

Streever, B. 2001. Saving Louisiana? The battle for coastal wetlands. Jackson: University Press of Mississippi.

Tall, D. 1993. From where we stand. Baltimore, MD: The Johns Hopkins University Press.

Turner, R.E. 1997. Wetland loss in the northern Gulf of Mexico: multiple working hypotheses. Estuaries 20(1):1-13.

Tutu, D. 2007/2008. We do not need climate change apartheid in adaptation. In UNDP [United Nations Development Program]. Fighting climate change: human solidarity in a divided world. Available online at http://hdr.undp.org/en/media/HDR_20072008_Summary_English.pdf (last accessed 7/8/13). Pp. 166.

UNDP [United Nations Development Program]. 2007/2008. Fighting climate change: human solidarity in a divided world. Available online at http://hdr.undp.org/en/media/HDR_20072008_Summary_English.pdf (last accessed 7/8/13).

US Energy Information Administration. 2009. Louisiana Energy Fact Sheet - October 2009. Available online at http://www.eia.gov/state/state-energy-profiles-print.cfm?sid=LA (last accessed 29/11/13).

Vine, D. 2009. Island of shame: the secret history of the U.S. military base on Diego Garcia. Princeton, New Jersey: Princeton University Press.

Watts, M.J. 1983. The political economy of climatic hazards: a village perspective on drought and peasant economy in a semi-arid region of West Africa. Cahiers d'Études Africaines 23(89/90): 37-72. 
Watts, M.J. 2003. Economies of violence: more oil, more blood. Economic and Political Weekly 38(48): 5089-5099.

Watts, M.J. 2004. Antinomies of community: some thoughts on geography, resources and empire. Transactions of the Institute of British Geographers 29(2): 195-216.

Watts, M.J. 2012. A tale of two gulfs: life, death, and dispossession along two oil frontiers. American Quarterly 64(3): 437-467.

Westman, C. N. 2013. Social impact assessment and the anthropology of the future in Canada's tar sands. Human Organization 72(2): 111-120.

The White House. 2010. Executive Order 13554 - Gulf Coast Ecosystem Restoration Task Force. October 5. Available online at http://www.whitehouse.gov/the-press-office/2010/10/05/executive-order13554-gulf-coast-ecosystem-restoration-task-force (last accessed 24/11/13).

Whyte, K.P. 2013. Justice forward: tribes, climate adaptation and responsibility in Indian country. Climatic Change 120(3): 517-530.

Wildcat, D.R. 2013. Introduction: climate change and indigenous peoples of the USA. Climatic Change 120(3): 509-515.

Wildcat, D.R. 2009. Red Alert! Saving the planet with indigenous knowledge. Golden, CO: Fulcrum Publishing.

Wisner, B. 2004. Assessment of capability and vulnerability. In G. Bankoff, G. Franks and D. Hilhorst (eds.) Mapping vulnerability: disasters, development and people. London: Earthscan. Pp. 183-193.

Wolf, E. 1999. Envisioning power: ideologies of dominance and crisis. Berkeley: University of California Press. 